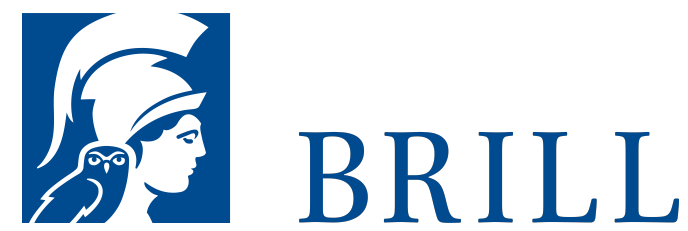

\title{
Hebrews in Contexts
}

\section{Editors: Gabriella Gelardini and Harold Attridge}

Scholars of Hebrews have repeatedly echoed the almost proverbial saying that the book appears to its reader as a "Melchizedekian being without genealogy". For such scholars the aphorism identified prominent traits of Hebrews, its enigma, its otherness, its marginality. Although Franz Overbeck might unintentionally have stimulated such correlations, they do not represent what his dictum originally meant. Writing during the high noon of historicism in 188o, Overbeck lamented a lack of historical context, one that he had deduced on the basis of flawed presuppositions of the ideological frameworks prevalent of his time. His assertion made an impact, and consequently Hebrews was not only "othered" within New Testament scholarship, its context was neglected and by some, even judged as irrelevant altogether. Understandably, the neglect created a deficit keenly felt by more recent scholarship, which has developed a particular interest in Hebrews' contexts. Hebrews in Contexts, edited by Gabriella Gelardini and Harold W. Attridge, is an expression of this interest. It gathers authors who explore extensively on Hebrews' relations to other early traditions and texts (Jewish, Hellenistic, and Roman) in order to map Hebrews' historical, cultural, and religious identity in greater, and perhaps surprising detail.

Readership

In accordance with the concept of this book its authors include not only experts in New Testament scholarship but also of specialists in Hebrew Bible, Second Temple Judaism, Talmud, and Classics. Accordingly, this volume will be of interest not only for students of Hebrews and the New Testament but also for colleagues engaged in those other subject areas.

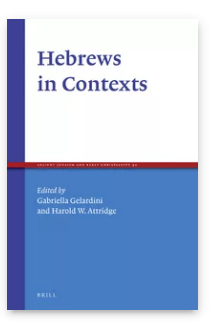

Language:

English

Subjects: New

Testament \&

Early Christian

Writings,

Biblical Studies,

Ancient

Judaism, Biblical

Studies, Hebrew

Bible, Biblical

Studies,

Philosophy,

Theology \&

Science, Jewish

Studies, Early

Church \&

Patristics,

Biblical Studies

Publisher: Brill

Series:

Ancient Judaism

and Early

Christianity,

Volume: 91

E-Book (PDF)

Released online:

og May 2016

ISBN: 978-90-

04-31169-5

List price

USD \$201.00 
Publication date:

Gabriella Gelardini is Associate Professor of New Testament (Privatdozentin) at the Theological Faculty of the University of Basel. Apart from numerous lexicon articles, essays, and short entries on Hebrews, her publications on the Epistle include, "Verhärtet eure Herzen nicht": Der Hebräer, eine Synagogenhomilie zu Tischa be-Aw (Brill, 2007) and the edited volume Hebrews: Contemporary Methods-New Insights (Brill, 2005; SBL, 2008).

Harold W. Attridge is the Sterling Professor of Divinity at Yale University Divinity School. He is the author of a commentary on Hebrews (Hermeneia, 1989) and numerous essays on the Epistle.

For more information see brill.com

Order information: Order online at brill.com +44330 3330049 | customerservices@brill.com Submission information: brill.com/authors

Titles published by Brill | Fink, Brill | mentis or Brill | Schöningh: +49(o)71 5413279216 | brill@brocom.de

ISBN: $978-90-$

O4-31168-8

List price

USD $\$ 201.00$ 